\title{
Towards Understanding the Relation between Religions and Cultures in Southeast Asia
}

\author{
Joseph I. Fernando
}

\begin{abstract}
In the face of modernity and its erosion of traditional values, we need to preserve something of the wisdom of traditional culture. The traditional cultures have taken thousands of years to evolve and are necessary to preserve. They are the carriers of the accumulated wisdom of the people since Antiquity. They give man a sense of belonging, acceptance, and assurance. They enshrine the values, which define meaning, guide, motivate, and lead people to fulfillment. We find cultural traditions still alive in the rural communities of Southeast Asia. It is to these communities that we need to turn to guide us on our road to the future.
\end{abstract}

\section{The Significance of Religion}

Marx wrote in the Introduction to a Critique of Hegel's Philosophy of Right: "Religion is ... the imaginary realization of human being, because human being possesses no true reality; Thus the struggle against religion is indirectly the struggle against that world whose aroma is religion ... Religion is the opium of the people. The real happiness of people requires the abolition of religion, which is their illusory happiness." ${ }^{1}$ Feuerbach argued in his The Essence of Christianity that "the secret of theology is anthropology." Whatever man says about God is an expression in mystified terms of his knowledge about himself. "God is the imaginative projection of man's species-essence, the totality of his powers and attributes raised to the level of infinity ... man's knowledge of God is an attempt to perceive himself in the mirror of exteriority; man exteriorizes his own essence before he recognizes it in himself, and the opposition between God and man is a 'mystified' version of the opposition between the species-being and the individual ... Man asserts in God what he denies in himself."2

Joseph I. Fernando is a lecturer in philosophy at Assumption University of Thailand. This article originally appeared in Prajna Vihara: Journal of Philosophy and Religion 7, no. 2 (Jul.-Dec. 2006), which is published by the Graduate School of Philosophy and Religion, Assumption University of Thailand. 
Is religion really the opium of the people? The answer is both yes and no. There is a distinction between religion in principle and religion in practice. Religion in practice can be exploitative. In fact, exploitation by religion has been prevalent all over the world. One can think of the exploitative religious practices, for examples, in ancient India and Europe.

The materialists known as Lokayatikas or Charvakas in ancient India held that only this world or loka is real. "The materialist theory had a good deal to do with the repudiation of the old religion of custom and magic." 3 The common man was weighed down by the burden of rituals in India in the sixth century BC. Orthodox Hinduism was excessively ritualistic. Many could not afford the cost of the rituals. Without the rituals, it was almost impossible to establish contact with the deity. Religion was in the hands of the priests. Priesthood had become almost priest-craft: "The masses of men were addicted to the ceremonies and observances prescribed by those who lived on food provided by the faithful ... The priest who pretended to be the channel of divine power dominated the religion of the country ... he pretended to be in the confidence of the gods and addressed the needy: 'Son, make a sacrifice to God and a payment to me, and thy sins will be forgiven thee.' The system of salvation by silver could not answer to the deeper needs of the human heart." 4

Gautama Buddha was aware of this: "The cruel rites with which worship was accompanied shocked the conscience of Buddha." ${ }^{5}$ He searched for a way to free people from the clutches of ritualism. His departure from orthodox Hinduism was a protest against all that was not humane. He was silent on God but emphatic on the practice of morality. His stand could be said to be that it is not necessary to be vociferous about God but obligatory to be good and do good. As the Christian Scripture says: "Not everybody who says to me 'Lord! Lord!' will enter the kingdom of Heaven, but the one who does the will of my Father in Heaven.” ${ }^{6}$ Is it not the will of the Father in Heaven that people must be good and do good?

Marx, Nietzsche, and Freud vehemently opposed religion. For Marx, religion is part of the superstructure resting on the base of economics. In feudalistic Europe, the serfs would listen to the sermons by priests who exhorted them to obey their feudal masters. Their suffering on earth was negligible compared to the eternal happiness they would have in heaven after death. They were told: "You will get a pie in the sky after your die." But the serfs were in need of the pier "here and now." No wonder he considered religion as the opium of the people. Nietzsche was disgusted with the Christianity of his times and declared in his The Gay Science: "God is dead. 
God remains dead. And we have killed him” (aphorism 125). For Freud, religious beliefs are considered infantile illusions.

Yet just because religion has been abused by certain so-called religious people and others, it cannot merely be condemned as the opium of the people. Religion has been a panacea for the ills of the soul. In a country like India, from time immemorial there has been a longing to become one with the Divine. Earthly life has been understood as prelude to eternity. This longing expressed itself in simplicity, austerity, learning, meditation, and contemplation. This longing was manifest in philosophy, literature, music, painting, sculpture, dance, architecture, and so on, the antiquity of which is unparalleled in human history. Although secular themes too found their expression in human creation, the predominant theme was, of course, religious.

With the advent of Christianity, the barbaric tribes of Europe found themselves civilized and tamed. The barbarians were the Celts, Germans, Slavs, and others - "the non-Italic and non-Greek peoples of Europe who inherited the Greco-Roman civilization and formed most of the present-day European nations. Like the Italic peoples, they were speakers of Indo-European dialects." Many were called to a life of holiness. Towering intellectuals like St. Augustine, St. Anselm, St. Thomas Aquinas, and St. Bonaventure were holy men. The founding of monastic orders by St. Benedict, St. Dominic, and St. Francis of Assisi, the Gothic cathedrals and the cathedral schools that eventually evolved into such great universities as Oxford, Cambridge, Padua, and Salamanca; the works of artists like Michaelangelo and Leonardo da Vinci; and literary creations and immortal musical compositions - these were all inspired by religion. In the Islamic and Buddhist worlds, we also find amazing creations that evolved from deep religiosity.

Religion has been the bedrock of hope for millions of people down through the centuries. It has been the source of purpose and fulfillment in their lives. Religion has given them a reason to live and a meaning to their death. It has enabled them to live, to give, to forgive, to serve, to suffer for worthy causes, and to work for peace and unity. Without religion, the world would be engulfed in spiritual darkness. For millions of people, human life would be unthinkable without religion because they are guided by the precepts of their religions. The fact that people take their religions seriously indicates that man is not only a rational, social, and political animal, but also a religious animal. Scores of people have laid down their lives and are ready to do so even today in defense of the values upheld by their religions. Religion has a tremendous hold on man. Man, as a mortal being, realizes that death puts an end to his earthly existence. All his toil and moil will come to 
a halt one day. As Heidegger puts it, man is a being-towards-death. His life is fleeting, temporary, and finite. St. Thomas Aquinas demonstrates in him Summa Theologica that man has only one end: God. ${ }^{8}$ His happiness consists only in God, not in wealth, honors, fame, glory, power, bodily good, pleasure, some good of the soul, and created good. Is it not, then, wise to seek the ultimate reality, which is his final end and source of all happiness? Interestingly, Asia is the cradle of religions such as Hinduism, Buddhism, Jainism, Zoroastrianism, Judaism, Christianity, Islam, and so on. It is worth investigating into the relation between religions and cultures, especially in Southeast Asia.

\section{The Southeast Asian Context}

Plato aptly remarked that philosophy begins in wonder. Man is not only a wonderful being but also a wondering being. He wonders about the things around him, within him, and beyond him. This sense of wonder and the curiosity to search for answers to perplexing questions have led him to philosophy and religion. There have been several stages in the development of the religious consciousness of man from animism to monotheism. There is hardly any culture without religion. Religion has been a major force propelling great cultural accomplishments. The great epics of Ramayana and Mahabharata, the Angkor Wat temple complex in Cambodia and the Borobodur temple complex in Java are some examples of the impact of religion on literature and architecture, respectively.

A. L. Basham writes in his The Wonder that was India: "The whole of South-East Asia received most of its culture from India ... Other cultural influences, from China and the Islamic world, were felt in South-East Asia, but the primary impetus to civilization came from India." Traditionally, in mainland Southeast Asia, Burma/Myanmar, Laos, Thailand, Cambodia, and Vietnam have been Buddhist nations. Malaysia, Indonesia, and Brunei are predominantly Islamic nations. The Philippines is the only predominantly Christian nation in Asia. Singapore is truly a cosmopolitan city-state. The religions of Southeast Asia today are Buddhism, Islam, Christianity, Hinduism, and Sikhism. None of these religions were native to Southeast Asia. Indian Buddhist missionaries and Hindu priests, merchants, and settlers introduced Buddhism and Hinduism, respectively, in Southeast Asia from India. The Sufi merchants and masters from India, Persia, and Arabia introduced Islam into Southeast Asia.

The Filipinos became Catholics due to the colonization of the Philippines by the Spaniards in the sixteenth century and some of them later became 
Baptists due to the American presence in the country. Although these religions have contributed much to the cultures of Southeast Asia, the natives of these lands had their own cultures prior to the advent of these religions. What are the values and practices of these indigenous cultures? Were these cultures enriched or hampered by the advent of the new religions? Have there been conflicts between the native cultures and the adopted religions? How much of the native culture is preserved? Has there been an enculturation of these religions in Southeast Asia? If some of the native cultural practices were abandoned in the wake of embracing a new religion, can we rediscover their values and preserve them for posterity? This is an urgent task today, especially in the context of globalization, which allegedly threatens, to some extent, the existence and continuity of our cultures.

The Filipinos converted by the Spaniards became more like Spanish Christians, just as those converted by the Portuguese in Goa, India, became like Portuguese Christians. Yet they have also developed their own Asian Christianity identity that is distinct from their western roots. Likewise, to be a Muslim in Indonesia or Malaysia is not to be exactly like a Muslim in Saudi Arabia. A Muslim in Saudi Arabia is a product of Arabic culture with its own history, ecology, and traditions. Indonesian and Malaysian cultures existed long before the advent of Islam in these countries.

Has there been a symbiotic relationship between religions like Islam and Christianity and the cultures of Southeast Asia? In this context, what comes to mind are the pioneering efforts of the Italian Jesuits Matteo Ricci in China and Robert de Nobili in India in the sixteenth and seventeenth centuries respectively, with regard to the enculturation of Christianity. Ricci and de Nobili attempted to present Christianity not as a western religion with western trappings, but as a universal faith of salvation to people everywhere. They believed that the Christian faith must incarnate itself in the native cultures of the people. Ricci and de Nobili were not mere missionaries; rather, they were visionaries of enculturation. Nearly 400 years later, the Catholic Church for the first time spoke about the need for enculturation and the interrelationship between the Gospel and culture in the Vatican II documents. ${ }^{10}$ In the light of this paradigm of enculturation, what is the impact of religions like Christianity and Islam on Southeast Asian cultures?

Significantly, when a native culture encounters a non-native religion, there may be a mutual impact. For example, Christianity had its impact on Indian culture. The Christian presence in India influenced the abolition of sati (burning the widow on her husband's pyre), of child marriage, and of the devadasi system (temple prostitution). The Christian missionaries threw open 
their schools to all children in a country where some sections of society were traditionally denied education. The Sermon on the Mount profoundly influenced Gandhi in his advocacy of non-violence. Hinduism has had its impact on Christianity. The Christians learnt from the Hindus to appreciate religious tolerance. The Hindu belief in the divine presence in natural phenomena - the trees, mountains, rivers, and so on - has enabled the Christians to understand better divine immanence in the universe besides being aware of the transcendence of God. Likewise, has there been a mutual impact of religions and cultures in Southeast Asia? It may be said that religion is the core of culture. Just as culture preserves religion within itself, religion too has to affirm the values of the culture in which it is embedded.

Religion and ethnicities seem to go hand in hand in Southeast Asia. It appears as if to be Thai, Burmese, or Cambodian is to be Buddhist; to be Indonesian or Malay is to be a Muslim, and to be a Filipino is to be a Christian. The religion of the majority seems to determine the national character. This is not how Southeast Asia should be. In fact, religions transcend ethnicities and are universal. The minorities too play significant roles in the life of the nation. Some microscopic minorities do make enormous contributions to the nation. For example, the Christians in Asia have been pioneers in the fields of education and health care. People of all religions constitute the rich diversity of the nation. The minorities are not left to the mercy of the majority in a democratic polity. Democracy is where all the citizens are equal under the law and have equal opportunities. A nation is judged by the character, dynamism, and quality of life of its citizens, which include both the majority and the minorities. Therefore, to be Thai is more than to be Buddhist; it is also to be Muslim, Christian, and so on. To be Filipino is also to be Muslim. To be Indonesian or Malaysian is also to be Christian, Hindu, Buddhist, and so on.

One's identity as belonging to a particular religious or ethnic community cannot be a threat to another's identity as belonging to another religious or ethnic community. As autonomous persons, people profess and practice a religion that they find meaningful. Therefore, there is no question of a threat to anybody's identity as long as the citizens recognize that value of peaceful coexistence, mutual appreciation, cooperation, and collaboration. A threat arises when religious groups become fundamentalist or fascist, and acquire misguided motives and vested interests. In fact, the Church or the religious body is the only moral voice of society. Holiness is nurtured in a religious environment. More holy men and women are needed today than in any other time in human history. Holy persons who are committed to the love of the 
divine and the human are called upon to bring light, love, and healing to the lives of people. In the absence of holiness, spirituality, devotion, and service, mere organization and administration of the Church or the religious body would be lifeless and meaningless. Without holy men and women who are meek, simple, caring, and loving, the world would be a hell. Truly holy persons transcend the barriers of language, religion, race, and ethnicity and reach out to all human beings in loving service. Such persons respect the sentiments, freedom, and rights of others. For example, truly holy Hindus and Muslims would not impose on others abstinence from eating beef and pork, respectively. Similarly, those living in predominantly Hindu and Muslim areas would voluntarily abstain from eating beef and pork, respectively, as a mark of respect for and identity with the brethren of other religions.

St. Paul expresses this concern so well in his letter to the Romans (14:15-23):

But if you hurt your brother because of a certain food, you are no longer walking according to love ... the kingdom of God is not a matter of food and drink; it is justice, peace, and joy in the Holy Spirit ... Let us look, then, for what strengthens peace and makes us better. Do not destroy the work of God because of food ... And it may be better not to eat meat or drink wine, or anything else that causes your brother to stumble. Keep your own belief before God, and happy are you if you never act against your own belief. Instead, whoever eats something in spite of his doubts is doing wrong, because he does not act according to his belief, and whatever we do against our conscience is sinful.

Religion, of course, primarily meets the moral and spiritual needs of man. It guides him to the realization of ultimate reality. This does not mean that religion is indifferent to the other aspects of human life - the political, economic, social, cultural, technological, and so on. Religion sees man in his wholeness. Man is not a fragmented being. Religion guides the whole man to his final destiny. So, all aspects of human life are the concerns of religion. Religion seeks to integrate all these aspects of life into a meaningful whole. Whenever human wholeness is threatened by politics, economics, business, technology, and so on, religion has to intervene in an effort to redeem it. Moreover, religious bodies have to cooperate with governmental and nongovernmental agencies to promote human welfare. Such an alignment presupposes solidarity among religions themselves.

Like the World Parliament of Religions, there should be a Southeast Asian Confederation of Religions to promote social action. Each Southeast 
Asian nation should have a federation of religions. All these federations can be formed into a larger Confederation of Religions. Such organizations can enhance the effectiveness of each religion, in solidarity with others, for social action. Religions must come out of their isolation and forge a unity for social action. Sometimes religions are represented on the occasion of an inter-religious prayer service. This is not enough. Despite the difference of doctrines among themselves, they have the common goal of serving man. This common goal is sufficient to lead them to form a Confederation of Religions with a view to work for human wholesomeness in the context of modernization, technology, and urbanization.

\section{Modernization, Religion, and Culture in Southeast Asia}

I would like to probe into the role of religion and culture with regard to the quality of life in Southeast Asia in the context of modernization. Modernization is a postcolonial phenomenon in Asia. After gaining independence from their former colonial masters, the nations of Asia, with their right to selfdetermination, embarked on the course of modernization. Modernization is the fruit of science and technology. It includes industrialization, effective means of transport, communications, medical care, time-saving utilities, liberal education, international trade, and so on. Modernization was expected to improve the quality of life. But has the quality of life really improved in these nations? What is meant by the quality of life? Does it consist only of economic development? Although economic development certainly makes a major contribution, there are several other desirable things to improve the quality of life. The quality of life has much to do with what it means to be human and what is a good life. Does a good life mean only the satisfaction of economic needs? No. Man has other needs to fulfill in order to be human. What are they?

For man to live a truly human life means primarily to live with dignity. His dignity and worth as a person should be affirmed. This means that he should live a decent life. Decency requires the satisfaction of basic needs such as food, shelter, and clothes. Decency also implies rights and freedom: the right to life, security, livelihood, education, property, and so on; freedom of thought, expression, and assembly; freedom of belief and opinion; and freedom of mobility, tastes, and pursuits. A decent life can be quantitative and qualitative - quantitative insofar as the things people need are measurable; qualitative insofar as people achieve their well-being in terms of relationships, community, freedom, and creativity. Amartya Sen speaks of 
development not merely as economic, but also as contributing to the enhancement of the capabilities of people. ${ }^{11}$ People have many capabilities, such as to live a healthy life, to develop their talents, to decide freely what is good for them, to pursue careers of their choice, to interact meaningfully with others, to develop their emotions, to be creative, to participate in activities of the community, to be part of decision-making, to work for environmental protection, to promote peace and harmony, and so on. The development of numerous capabilities contributes to the growth of persons and communities.

Although modernization has accelerated economic growth, it has caused some other problems in the region. There has been an exodus from the rural areas to the cities in search of job opportunities. Overpopulation in the cities affects the quality of urban life. Congested traffic, pollution, overcrowding, shantytowns, poor sanitation, crime, mafia, and so on are the problems in the cities. The exodus to the cities affects the rural economy too. Farming suffers, the environment decays, cottage industries and handicrafts shrink, and villages wear a forlorn look due to neglect, desertion, and lack of resources. Both the cities and villages need redemption. They can be saved from further ruin by limiting the exodus from the villages to the cities. One of the most urgent tasks today is rural development. The villages must be developed in such a way that the necessary amenities are available to the villagers so that they do not migrate to the cities in search of them. As far as possible, people must be enabled to live satisfying lives in the developed villages.

Modernization has its impact on the moral values of the people too. Moral values like honesty, integrity, and so on tend to suffer a setback in a highly competitive and success-driven society. Interpersonal relations are likely to be measured in terms of economics. Family, as the most fundamental and vital unit of society, is threatened by divorce, unfaithfulness, separation, and so on. Money-making activities take too much of one's time, leaving little time for spending with family, caring for others, and/or performing meaningful religious rituals to maintain cohesion in the family and community. Gradually, cultural traditions slip out of one's consciousness within this concrete jungle. In this context, how important it is to understand why Gadamer upholds the importance of tradition!

Asia is traditionally known for the values of simplicity, religiosity, hospitality, and joy. The Asians have generally preferred a simple lifestyle that is marked by possession of a few things needed for daily use. Consumerism and greed have crept into Asian societies because of globalization and aping the West. A difficult task is how to strike a balance between simplicity and modernization. A profound sense of religiosity generates hope, meaning, and 
purpose in the lives of the people of Asia. The Asians view earthly existence as transitory and seek the ultimate reality according to their religious traditions. But of late, the values of religion have been affected by consumerism, materialism, and hedonism. Traditional Asian hospitality has been transformed into the hospitality industry today. Hospitality has become a marketable commodity. How hard it is to be hospitable, warm, generous, and caring without being paid! Joy has been a distinguishing mark of the Asian spirit. The Asians laugh, joke, and are cheerful even if they are poor. They are seldom given to despair, depression, and gloom. Dominique Lapierre's The City of Joy is an ample proof of this. ${ }^{12}$

\section{Conclusion}

How can the erosion of cultural values be stopped? In what ways can culture be preserved and promoted? How is a holistic approach to life possible? Searching for answers to these questions is essential, because it is part of one's search for meaning in life. What is the role of religion in contributing to a good life? What are the dynamics of religion in providing meaning to life? In Southeast Asia, has religion been hijacked by the economy or has it adapted itself to the changing times or compromised with modernization? Has any religion undertaken a critique of Southeast Asian society, which it seeks to serve? It is a matter of great concern not to lose one's consciousness of cultural heritage amidst the flux of modernization.

Another concern is how religion can interact meaningfully with culture. Such an interaction presupposes dialogue among religions themselves. The religions of Southeast Asia, in trying to understand more of each other, can foster friendship and solidarity for social action. Dialogue requires openness to plurality, diversity, and recognition of the "other.” They need not shy away from dialogue, saying that dialogue is a western concept and that Christians are interested in it only to convert others. Dialogue is not for conversion, but to understand the "other." All understanding eventually leads to selfunderstanding. There is a need for committed dialogue among religions.

The purpose of religions coming together in dialogue is not to brag about each one's religion. It is not to say: "My religion is the only true religion," as if others are false. Of course, one may be legitimately proud of one's religious heritage and rightly so. This does not mean that one can look down upon other religions. In dialogue, a sincere attempt is made to understand the other's position. As Gadamer says, dialogue is guided by the subject matter and not by the personalities involved in it. It requires openness and respect. 
As persons seek to understand each other in dialogue, the emphasis is not on the theoretical. Dialogue is praxis. It is a commitment and an opening towards grasping the common ground on which we all stand. It is a revelation of our shared humanity and the human condition that is inescapably everyone's lot. Religions coming together in dialogue ought to seek the praxis of addressing situations that need to be rectified. Buddhism, Islam, Christianity, and the other religions of Southeast Asia need to create a platform for praxis. In a joint venture, they can address a number of issues more effectively. This is the way religions become credible in a society where many tend towards materialism, skepticism, individualism, and indifference. Religion ought to retain its moral voice in relation to the concrete situations in which people find themselves.

In the absence of dialogue among religions, the people of Southeast Asia may not visualize their shared destiny and will lack a sense of direction towards the future. Religion needs to do a lot of soul-searching with regard to being a moral force in defining what it is to be human. To grasp what it is to be human has much to do with overcoming the situations people are in: human trafficking, profiteering, racketeering, and so on. In fact, the call to rediscover the values of religion and culture in Southeast Asia is linked to the destiny of the people of the region. The perennially relevant question remains: What does it mean to be human?

Traditional cultures have taken thousands of years to evolve and are worth preserving, since they are the carriers of the accumulated wisdom of the people since Antiquity. Culture gives man a sense of belonging, acceptance, and assurance. Culture enshrines the values that define meaning as well as guide, motivate, and lead people to fulfillment. This does not mean that everything in a cultural tradition is good. Culture needs purification too. Superstitious beliefs, for example, are not wholesome. The caste system is an aberration and a blot on Indian culture. Caste is dehumanizing, divisive, discriminatory, oppressive, and fascist. It recognizes the intrinsic dignity and worth of only some - not all - persons. It builds walls - not bridges between people. It is a denial of brotherhood.

Modernization may be a threat to traditional cultures. With the advent of modernization, there is a tension between change and continuity. How much of the traditional culture changes, and how much of it continues? How best can modernization and cultures be integrated? Does religion have a role in this? Religion cannot be a mute witness to the destruction of traditional cultures. People need to be part of traditional cultures. Culture, like the hearth and home, is necessary for man; without it, he will be a wanderer and dis- 
possessed. The rural communities, with their closer times and bonds of union, should be preserved as an antidote to the faceless technological society that may dehumanize people and threaten the survival of nature. Whatever contributes to human wholesomeness, a sense of belonging, loveliness, beauty, rustic simplicity, and the joy of being rooted in the soil must be protected, preserved, and fostered.

\section{Endnotes}

1. Leszek Kolakowski, Main Currents in Marxism, 1. The Founders (New York: Oxford University Press, 1989), 128-29.

2. Ibid., 115.

3. S. Radhakrishnan, Indian Philosophy (New York: Oxford University Press, 2000), 283.

4. Ibid., p. 356.

5. Ibid., 354.

6. The Bible, Matthew 7:21.

7. New Catholic Encyclopedia (Washington, DC: The Catholic University of America, 1967), 2:86.

8. Summa Theologica, I-II, Q. 1-5.

9. A. L. Basham, The Wonder that was India (New Delhi: Rupa \& Co., 2001), 485.

10. Vatican II Documents, “Gaudium et spes,” 53-62.

11. Amartya Sen, Development as Freedom (New York: Anchor Books, 1999).

12. Dominique Lapierre, in his The City of Joy, narrates his unique experiences in Calcutta, where he finds the people strikingly joyful although many of them are poor. 